Febrianto, Et al. / Jurnal Pendidikan Teknologi Pertanian, Vol. 4 (2017)

\title{
ANALISIS PENERAPAN MEDIA PEMBELAJARAN PREZI TERHADAP HASIL BELAJAR SISWA KELAS X TPHP PADA MATA PELAJARAN PENGENDALIAN MUTU DALAM PROSES PENGOLAHAN DI SMK NEGERI 3 TAKALAR
}

\section{Analysis Of Prezi Learning Media Applications To Learning Results Student Class X Tphp On Quality Control Language In Processing Process In Smk Negeri 3 Takalar}

\author{
Febrianto, Muh.Rais, Nurmila \\ Program Studi Pendidikan Teknologi Pertanian Fakultas Teknik \\ Universitas Negeri Makassar \\ Email: febrianto080294@gmail.com
}

\begin{abstract}
Abstrak
Penelitian ini adalah penelitian tindakan kelas (classroom action research) yang bertujuan meningkatkan hasil belajar siswa pada mata pelajaran pengendalian mutu dalam proses pengolahan kelas $\mathrm{X}$ program keahlian teknologi pengolahan hasil pertanian SMK Negeri 3 Takalar dengan penggunaan media pembelajaran prezi. Subjek penelitian ini adalah siswa kelas $X$ program keahlian teknologi pengolahan hasil pertanian SMK Negeri 3 Takalar pada semester genap tahun ajaran 2016/2017 yang terdiri dari 29 siswa. Penelitian ini dilaksanakan dalam dua siklus yang terdiri dari empat kegiatan, yaitu: perencanaan, pelaksanaan, pengamatan/observasi dan refleksi. Pengumpulan data aktivitas siswa dan hasil belajar dilakukan dengan menggunakan lembar observasi dan lembar tes di akhir pembelajaran pada siklus I dan siklus II. Data yang terkumpul dianalisis secara kuantitatif dan kualitatif. Berdasarkan hasil penelitian dapat disimpulkan bahwa penggunaan media pembelajaran Prezi dapat meningkatkan hasil belajar siswa kelas X TPHP SMK Negeri 3 Takalar.
\end{abstract}

Kata Kunci: Hasil Belajar, Media Pembelajaran Prezi.

\begin{abstract}
This research is a classroom action research, which aimed to improve student learning outcomes on the quality control of processing subject in class $X$ agricultural processing technology expertise SMK Negeri 3 Takalar with the use of teaching media, Prezi. The subjects of this research were the students of class $X$ agricultural processing technology expertise SMK Negeri 3 Takalar in the second semester of academic year 2016/2017 that consist of 29 students. This study was conducted in two cycles consisting of four step: planning, implementation, monitoring/observation and reflection. The collection data activities of students learning outcomes is done by using observation sheet and test sheet at the end of the study in the first cycle and the second cycle. The data were analyzed quantitatively and qualitatively. Based on the results of this study concluded that the use of Prezi can improve the learning outcomes of class X TPHP SMK Negeri 3 Takalar.
\end{abstract}

Keywords: Learning Outcomes, Teaching Media Prezi. 


\section{PENDAHULUAN}

merupakan suatu proses jangka panjang yang sudah menjadi bagian tidak terpisahkan dalam kehidupan di dunia. Melalui pendidikan, baik pendidikan formal, informal, maupun non-formal secara sistematis, terprogram, dan berjenjang akan menghasilkan manusia-manusia berkualitas. Sebagaimana yang tercantum dalam tujuan pendidikan nasional dalam Undang-Undang No 19 Tahun 2013 Tentang Sistem Pendidikan Nasional yang berbunyi: berkembangnya potensi peserta didik pendidikan agar menjadi manusia yang beriman dan bertakwa kepada Tuhan Yang Maha Esa, berakhlak mulia, sehat, berilmu, cakap, kreatif, dan menjadi warga negara yang mandiri serta bertanggung jawab.

Pada era global, teknologi baru terutama media mempunyai peranan penting dalam proses pembelajaran. Media merupakan bagian yang tidak terpisahkan dalam proses belajar mengajar demi tercapainya tujuan pendidikan pada umumnya

dan tujuan pembelajaran di sekolah pada khususnya. Terkait dengan kehadiran media, Arsyad (2013), menjelaskan bahwa perkembangan ilmu pengetahuan dan teknologi semakin mendorong upaya-upaya pembaharuan dalam pemanfaatan hasil-hasil teknologi dalam proses belajar. Para guru dituntut agar mampu menggunakan alat-alat yang dapat disediakan oleh sekolah dan tidak menutup kemungkinan bahwa alat-alat tersebut sesuai dengan perkembangan dan tuntutan zaman.

Agar pembelajaran efektif dan fungsional maka fungsi media pembelajaran sangat penting untuk dimanfaatkan. Pemakaian media dalam proses pembelajaran dimaksudkan untuk meningkatkan daya serap siswa terhadap informasi atau materi pembelajaran yang diberikan. Efektifitas penggunaan media pembelajaran sangat tergantung pada derajat kesesuaiannya dengan materi yang akan diajarkan serta tergantung juga pada keahlian guru dalam menggunakan media tersebut.

Hasil belajar siswa ditentukan oleh berbagai faktor yang mempengaruhinya baik faktor dari dalam (motivasi, minat, bakat, kecerdasan) maupun faktor dari luar (lingkungan, keluarga, teman, media pembelajaran, metode pembelajaran). Salah satu faktor dari diluar individu adalah tersedianya media pembelajaran yang memberi kemudahan bagi siswa untuk belajar sehingga proses belajar berlangsung dengan baik.

Berdasarkan hasil observasi yang dilakukan di SMK Negeri 3 Takalar menunjukan bahwa secara umum masih banyak guru belum memanfaatkan penggunaan media pembelajaran yang merupakan salah satu faktor penunjang hasil belajar siswa, dengan alasan kurang ahli dalam membuat media pembelajaran.

Keadaan yang seperti demikian menyebabkan hasil belajar siswa pada mata pelajaran penerapan konsep mutu hasil pertanian memperoleh nilai di bawah standar kriteria ketuntasan minimal (KKM) yaitu 70 . Hanya sekitar 28 siswa yang lulus dengan nilai rata-rata $71-100$ dengan presentasi $73 \%$ sementara indikator keberhasilan yang ingin dicapai adalah $80 \%$ atau 31 orang jumlah siswa yang harus lulus pada mata pelajaran tersebut.

Pada kenyataannya, berdasarkan wawancara dengan beberapa siswa, mereka sangat menginginkan suasana pembelajaran yang menarik dan bervariasi terlebih lagi pada mata pelajaran pengendalian mutu dalam proses pengolahan yang menitikberatkan pada ranah pengetahuan. Oleh karena itu seorang pendidik harus mampu membuat media pembelajaran yang menarik agar siswa tidak merasa jenuh.

Pembelajaran pengendalian mutu dalam proses pengolahan terdapat materimateri tentang cara pengendalian mutu pada proses pengolahan produk pertanian. Sebagai contoh dari materi pengendaliam mutu adalah Good Manufacturing Product. 
Materi tentang Good Manufacturing Product ini berupa cara pengendalian mutu produk yang terstruktur yang sulit diserap oleh siswa tanpa menggunakan media pembelajaran yang bisa menampilkan tahap-tahap pengendalian secara sistematis dan terstruktur bagaimana pengendalian mutu tersebut.

Salah satu media yang dapat digunakan terkait dengan hal tersebut adalah media pembelajaran Prezi. Prezi merupakan sebuah perangkat lunak untuk presentasi berbasis internet Selain untuk presentasi, Prezi juga dapat digunakan sebagai alat untuk mengeksplorasi dan berbagi ide di atas kanvas virtual. Prezi menjadi unggul karena program ini menggunakan Zooming User Interface (ZUI), yang memungkinkan pengguna Prezi untuk memperbesar dan memperkecil tampilan media presentasi. Prezi digunakan sebagai alat untuk membuat presentasi dalam bentuk linier maupun nonlinier, yaitu presentasi terstruktur sebagai contoh dari presentasi linier, atau presentasi berbentuk peta-pikiran (mind-map) sebagai contoh dari presentasi non-linier.

Media pada Prezi, teks, gambar atau video dan media lainnya di tempatkan di atas kanvas presentasi, dan dapat di kelompokan ke dalam bingkai-bingkai yang telah disediakan. Pengguna kemudian menentukan ukuran relatif dan posisi antara semua obyek presentasi dan dapat mengitari serta dapat menyorot obyek-obyek tersebut. Untuk membuat presentasi linier pengguna dapat membangun jalur navigasi presentasi yang telah di tentukan sebelumnya. (Noer, 2014)

Media pembelajaran ini dapat membantu guru dalam menyampaikan materi pembelajaran tentang penerapan konsep mutu, karena media ini memiliki kelebihan dapat dibuat menjadi presentasi linier dalam arti presentasi dalam bentuk terstruktur dengan tampilan yang berurutan dan bisa menampilkan gambar atau video sehingga memudahkan siswa untuk memahami materi pengendalian mutu dalam proses pengolahan secara sistematis dan terstruktur.

Beberapa penelitian sebelumnya salah satunya adalah penelitian Suharjanto, (2013) yang mengemukakan bahwa penerapan media Prezi dapat meningkatkan minat belajar siswa.

Berdasarkan uraian di atas tersebut dipandang penting dilakukannya penelitian yang serupa yaitu tentang. Analisis Penerapan Media Pembelajaran Prezi terhadap Hasil Belajar Siswa Kelas X TPHP pada Mata Pelajaran Pengendalian Mutu Dalam Proses Pengolahan di Smk Negeri 3 Takalar

Masalah yang akan dikaji dalam penelitian ini adalah: "Seberapa besar Peningkatan Hasil Belajar Siswa Kelas X TPHP dengan Menggunakan Media Prezi pada mata pelajaran pengendalian mutu dalam proses pengolahan di SMK Negeri 3 Takalar?

Tujuan penelitian ini adalah Untuk mengetahui seberapa besar peningkatan hasil belajar siswa Kelas X TPHP dengan menggunakan media Prezi pada pengendalian mutu dalam proses pengolahan di SMK Negeri 3 Takalar Manfaat yang diharapakan peneliti dari Penelitian Tindakan Kelas ini dapat dijadikan bahan informasi sebagi masukan bagi lembaga-lembaga pendidikan yang berguna untuk meningkatkan mutu pendidikan dan menambah wawasan di bidang pendidikan dan pengajaran terutama menyangkut media pembelajaran Prezi. Bagi guru adalah untuk meningkatkan mutu proses belajar mengajar (mengembangkan diri) dengan menggunakan model pembelajaran yang bervariasi untuk meningkatkan mutu kelulusan dan kompotensi siswa. Bagi Peneliti untuk menambah pengetahuan dan pengalaman serta sebagai bahan acuan bagi penelitian selanjutnya. 


\section{METODE PENELITIAN}

Penelian ini adalah Penelitian Tindakan Kelas (Classroom Action Research) yang dilaksanakan dalam siklus berulang, dimana setiap siklus terdiri atas rangkaian empat kegiatan yaitu, perencanaan tindakan, pelaksanaan tindakan, observasi (evaluasi), dan refleksi.

Penelitian ini dilaksankan di SMK Negeri 3 Takalar Jalan Hamzah Daeng Tuppu No. 1 Kelurahan Paddinging Raya, Kecamatan Sanrobone, Kabupaten Takalar. Waktu penelitian pada semester genap tahun ajaran 2015/2016. Adapun yang menjadi subjek penelitian ini adalah siswa Kelas $X$ TPHP di SMK Negeri 3 Takalar yang berjumlah sebanyak 29 orang. Teknik pengumpulan data pada penelitian ini melalui metode observasi dan metode tes hasil belajar

\section{Prosedur Penelitian}

Prosedur Penelitian Tindakan Kelas (PTK) ini direncanakan paling minimal dua siklus. Setiap siklus dilaksanakan dengan 3 kali pertemuan (3 jam pelajaran) sesuai dengan perubahan yang ingin dicapai antara siklus I dengan siklus II yang merupakan komponen yang saling berkaitan.

Indikator keberhasilan merupakan tolak ukur tingkat ketercapaian dari tindakan yang diberikan. Berikut indkator keberhasilan yang ingin dicapai. Penelitian tindakan kelas ini dikatakan berhasil apabila hasil belajar siswa rata-rata mencapai nilai kriteria ketuntasan minimal (KKM) 70 sekurangkurangnya $80 \%$ dari jumlah siswa pada kelas $X$ TPHP di SMK Negeri 3 Takalar.

\section{HASIL DAN PEMBAHASAN}

Data hasil belajar siswa dari pelaksanaan siklus I dan siklus II pada pembelajaran pengendalian mutu dalam proses pengolahan yang diperoleh dari hasil analisis statistik deskriptif yang dimaksudkan untuk mendeskripsikan atau menggambarkan hasil belajar siswa kelas $X$ TPHP SMK Negeri 3 Takalar dengan menggunakan media prezi. Skor hasil belajar siswa pada mata pelajaran pengendalian mutu dalam proses pengolahan kelas $X$ TPHP SMK Negeri 3 Takalar setelah diterapkan media pembelajaran berbasis prezi dapat dilihat pada Tabel 4.1 berikut:

Tabel 4.1 Hasil belajar peserta siswa kelas $X$ TPHP SMK Negeri 3 Takalar

\begin{tabular}{||l||c||c|c|c||}
\hline \multirow{2}{*}{ No } & \multirow{2}{*}{ Statistik } & \multicolumn{3}{|c|}{ Nilai statistik } \\
\cline { 3 - 5 } & & Sebelum Tindakan & Siklus I & Siklus II \\
\hline \hline 1 & \multirow{2}{*}{ Jumlah Siswa } & 29 & 29 & 29 \\
\hline 2 & Nilai Ideal & 100 & 100 & 100 \\
\hline \multirow{2}{*}{3} & Nilai Tertinggi & 56,7 & 80 & 86,67 \\
\hline & Nilai Terendah & 16 & 30 & 50 \\
\hline & Rata-rata & 40,23 & 55,74 & 75,40 \\
\hline
\end{tabular}

Ketuntasan belajar pada mata pelajaran pengendalian mutu dalam proses pengolahan dapat dilihat berdasarkan kemampuan peserta didik memahami konsep melalui media pembelajaran berbasis prezi. Dengan melihat kategori tuntas dan tidak tuntas dari memahami materi pelajaran pengendalian mutu dalam proses pengolahan maka diperoleh distribusi frekuensi dan persentase ketuntasan hasil belajar sebelum tindakan, siklus I, dan siklus II dapat dilihat pada tabel 4.2 berikut :

Tabel 4.2. Deskripsi ketuntasan belajar peserta didik kelas X TPHP SMK Negeri 3 Takalar

\begin{tabular}{|c|c|c|c|c|c|c|c|}
\hline \multirow{2}{*}{ Kategori } & \multirow{2}{*}{ Nilai } & \multicolumn{2}{|c|}{$\begin{array}{l}\text { Sebelum } \\
\text { Tindakan }\end{array}$} & \multicolumn{2}{|c|}{ Siklus I } & \multicolumn{2}{|c|}{ Siklus II } \\
\hline & & $\begin{array}{l}\text { Fre- } \\
\text { Kuensi }\end{array}$ & $\begin{array}{c}\text { Persen } \\
(\%)\end{array}$ & $\begin{array}{c}\text { Fre- } \\
\text { kuensi }\end{array}$ & $\begin{array}{c}\text { Persen } \\
(\%)\end{array}$ & $\begin{array}{l}\text { Fre- } \\
\text { kuensi }\end{array}$ & $\begin{array}{c}\text { Persen } \\
(\%)\end{array}$ \\
\hline $\begin{array}{l}\text { Tidak } \\
\text { Tuntas }\end{array}$ & $0-69$ & 29 & 100 & 19 & 65,51 & 4 & 13,80 \\
\hline Tuntas & $70-100$ & 0 & 0 & 10 & 34,49 & 25 & 86,20 \\
\hline \multicolumn{2}{|c|}{ Jumlah } & 29 & 100 & 29 & 100 & 29 & 100 \\
\hline
\end{tabular}

Berdasarkan hasil analisis kualitatif dan kuantitatif, terlihat pada dasarnya pelaksanaan pembelajaran menggunakan 
media pembelajaran berbasis prezi memberikan perubahan hasil belajar pada siswa. Hasil penelitian yang telah dilakukan dengan menggunakan media prezi dalam pembelajaran pengendalian mutu dalam proses pengolahan diperoleh adanya peningkatan hasil belajar pada siswa kelas $X$ TPHP SMK Negeri 3 Takalar dari siklus I ke siklus II.

Penggunaan media prezi dalam pembelajaran yang diterapkan seorang guru merupakan salah satu faktor yang menentukan ketercapaian hasil belajar peserta didik, karena media yang sesuai dengan materi yang akan diajarkan dapat mendorong semangat siswa dalam mengikuti proses pembelajaran sehingga mempermudah siswa dalam memahami materi yang diajarkan oleh guru yang tentunya akan dapat meningkatkan hasil belajar.

\section{Sebelum Tindakan}

Dari tabel 4.2 dapat di jelaskan bahwa rendahnya presentase ketuntasan hasil belajar siswa kelas $X$ TPHP SMKN 3 Takalar, dimana ketuntasn belajar sebesar $0 \%$ atau 29 orang siswa belum tuntas belajar. Hasil tersebut menunjukan bahwa tes awal (Pre-Test) secara klasikal belum tuntas belajar, karena siswa yang memperoleh nilai $\geq 70$ sebesar $0 \%$ atau dinyatakan tidak ada yang tuntas belajar. Oleh sebab itu diperlukan perencanaan sebelum menerapkan media pembelajaran prezi agar efektif dan fungsional pada mata pelajaran penegndalain mutu dalam proses pengolahan. Kegiatan perencanaan tindakan dilaksanakan sebelum pembelajaran dan penggunaan media prezi. Perencanaan ini meliputi:

a. Guru bersama peneliti mendiskusikan rancangan tindakan yang akan dilakukan kemudian disepakati bahwa pelaksanaan tindakan disetiap siklus sebanyak 2 kali pertemuan dengan alokasi waktu 135 menit per stau kali pertemuan b. Mengkaji kurikulum SMK Negeri 3 Takalar semester genap mata pelajaran pengendalian mutu dalam proses pengolahan yang berkaitan dengan tema penelitian yang dilakukan.

c. Melakukan dialog awal yang digunakan untuk permasalahn awal dan dijadikan pijakan untuk melakukan rencana perbaikan pembelajaran

d. Merancang program pembelajaran berupa Rencana Pelaksanaan Pembelajaran (RPP) sesuai dengan silabus untuk pelasanaan tindakan dengan menggunakan media Prezi

e. Membuat instrumen penelitian soal tes awal (Pre-test) untuk siklus I dan II untuk melakuka evaluasi disetiap akhir siklus dan selanjutnya dilakukan validasi instrumen penelitian kepada validator

f. Soal tes yang dirancang adalah soal pilihan ganda berjumlah 30 butir soal yang akan diujika kepada siswa pada pertemuan ke-3 sekaligus sebagi tes akhir siklus

g. Instrumen non tes yan berupa lembar observasi yang telah disiapkan dan dilakukan setiap petemuan berlangsung

\section{Siklus I}

Pada Siklus I berdasarkan tabel 4.2 masih ada 19 siswa dari 29 siswa yang menjadi subjek penelitian yang hasil belajarnya menunjukkan berada pada kategori tidak tuntas, jumlah tersebut menunjukan masih sangat rendahnya ketuntasan pada siklus I yakni hanya sekitar $34,49 \%$ data tersebut masih jauh dari indikator keberhasilan yang diinginkan yaitu $80 \%$, oleh sebab itu di perlukan perbaikanperbaikan untuk melanjutkan ke siklus berikutnya agar hasil belajar siswa dapat meningkat dan memenuhi kriteria ketuntasan minimal dan indikator keberhasilan yang ingin dicapai. Faktor-faktor yang menyebabkan hasil belajar siswa berada pada kategori tidak tuntas yaitu:

a. Guru masih sangat kurang baik dalam memotivasi siswa dan dalam menyampaikan tujuan pembelajaran. 
b. Guru masih kurang menumbuhkan partisipasi aktif dari siswa Guru tidak mengaitkan pelajaran yang akan diajarakan dengan materi sebelumnya.

c. Kurang siswa yang mencatat materi pelajaran yang diajarakan oleh guru

d. Masih banyak siswa yang terlihat kurang memperhatikan materi yang disampaikan oleh guru

e. Media prezi yang dibuat oleh guru masih belum sesuai dengan materi pelajaran sehingga efek kemenarikan media prezi belum terpenuhi

f. Penggunaan baground dan Tempelate pada media Prezi belum sesuai dengan materi yang akan diajarkan oleh guru sehingga siswa kurang memperhatikan dan sulit menyerap materi pelajaran dan mengurangi efek kemenarikan dari media prezi tersebut

Adapun langkah-langkah sebagai hasil refleksi Siklus I dalam pelaksanaan Siklus II meliputi

a. Guru harus lebih terampil dalam memotivasi siswa dan lebih jelas dalam menyampaikan tujuan pembelajaran.

b. Guru perlu mendistribusikan waktu secara baik dengan menambah informasi yang dirasa perlu untuk diberikan.

c. Guru harus lebih terampil dalam menumbuhkan partisipasi aktif siswa dalam proses pembelajaran.

d. Guru harus mampu menghubungkan pelajaran yang akan diajarakan dengan materi sebelumnya.

e. Pemberian modul agar siswa lebih fokus memperhatikan guru menjelaskan materi pelajaran.

f. Pemberian tugas rumah kepada peserta didik diakhir pembelajaran

g. Menyesuikan penggunaan fitur-fitur pada media prezi dengan materi pelajaran sehingga meningkatkan efek kemenarikan media prezi dan dapat memusatkan perhatian siswa selam proses pembelajaran

\section{Siklus II}

Siklus II dilakukan setelah merefleksikan pelaksanaan Siklus I, kemudian diperoleh gambaran tindakan yang dilakukan pada Siklus II sebagai perbaikan dari pelaksanaan Siklus I, sehingga hasil belajar yang diperoleh pada penelitian ini sesuai dengan yang diharapkan.

Pada siklus II peningkatan hasil belajar siswa telah mencapai standar KKM untuk mata pelajaran pengendalian mutu dalam proses pengolahan yaitu 70,00 serta mencapai ketuntasan klasikal yaitu $80 \%$ dari jumlah siswa yang ada. Hal ini dapat dilihat dari hasil belajar peserta didik kelas X TPHP yang menunjukkan nilai ketuntasan yang diperoleh dari hasil tes awal yaitu jumlah peserta didik yang tidak tuntas sebanyak 29 siswa atau $100 \%$, yang menggambarkan bahwa keseluruhan peserta didik pada kategori tidak tuntas, kemudian pada hasil belajar siklus I dengan jumlah siswa yang tidak tuntas sebanyak 19 orang dengan persentase $65,51 \%$ dan jumlah peserta didik yang tuntas sebanyak 10 orang dengan persentase $34,49 \%$. Selajutnya dari hasil tes siklus II dimana jumlah siswa yang tidak tuntas sebanyak 4 orang dengan persentase $13,80 \%$ dan jumlah siswa yang tuntas sebanyak 25 orang siswa dengan persentase $86,20 \%$

Berdasarkan tabel 4.2 diperoleh presentase ketuntasan belajar siswa pada siklus II sebesar $86,20 \%$ atau 25 orang siswa dari 29 siswa sudah tuntas belajar sedangkan $13,80 \%$ atau 4 orang siswa dari 29 siswa tidak tuntas belajar. Hasil tersebut menunjukan bahwa tes akhir siklus II secara klasikal sudah tuntas belajar, karena diperoleh presentase ketuntasan belajar sebesar $86,20 \%$ menunjukan telah memenuhi indikator keberhasilan yang dikehendaki yaitu $80 \%$.

Selain adanya peningkatan hasil belajar siswa, juga adanya peningkatan terhadap aktivitas peserta didik dalam proses pembelajaran. 
Penggunaan media pembelajaran prezi memberikan manfaat dan pengaruh yang sangat nyata dalam meningkatkan aktivitas siswa terutama pada hasil belajarnya. Sebagaimana dikemukakan oleh Rais (2015), dalam kesimpulannya menyebutkan presentasi prezi memberikan perolehan kemampuan mengingat konsep yang lebih baik karena penggunaan multimedia presentasi berbasis prezi memberikan efek kemenarikan dari sisi pendekatan multimedia.

Maka secara umum dengan menggunakan media pembelajaran berbasis prezi dapat meningkatkan hasil belajar siswa kelas X TPHP SMK Negeri 3 Takalar pada mata pelajaran pengendalian mutu dalam proses pengolahan.

\section{Kesimpulan}

Berdasarkan uraian data hasil belajar peserta didik pada mata pelajaran pengendalian mutu dalam proses pengolahan pada pembahasan hasil penelitian, maka dapat disimpulkan bahwa penerapan media pembelajaran berbasis prezi dapat meningkatkan hasil belajar siswa kelas X TPHP SMK Negeri 3 Takalar dari siklus I ke siklus II serta terjadi peningkatan positif aktivitas siswa kelas X TPHP SMK Negeri 3 Takalar.

\section{Saran}

Dari hasil penelitian yang diperoleh agar proses belajar mengajar pada mata pelajaran pengendalian mutu dalam proses pengolahan lebih memberikan hasil yang optimal bagi siswa maka disampaikan saran sebagai berikut:

a. Dalam penerapan media prezi pada proses pembelajaran diperlukan persiapan yang cukup matang dan keterampilan khusus sehingga guru harus mampu memilih ide yang cukup menarik untuk dituangkan kedalam kanvas virtual prezi. b. Diharapkan kepada guru-guru terkhusus guru SMKN 3 Takalar dapat mempertimbangkan media yang digunakan dalam proses pembelajaran sebagai upaya meningkatkan hasil belajar siswa yang lebih baik.

c. Untuk peneliti selanjutnya diharapkan dapat mengembangkan dan memperkuat hasil penelitian ini dengan melakukan penelitian selanjutnya dengan media yang berbeda

\section{DAFTAR PUSTAKA}

Arsyad, Azhar. 2013. Media Pembelajaran. Jakarta: PT Raja Grafindo Jakarta Persada.

Muhammad Noer. 2014. Belajar menggunakan software prezi destop, (online). (http://www.prezi/about/ diakses 14 januari 2016)

Rais, Muh. 2015. Pengaruh penggunaan multimedia presentasi berbasis prezi dan gaya belajar terhadap kemampuan mengingat konsep. Jurnal mekom, (on line), vol. 2, nomor. 1,(http://www.ftunm.net/images/Mekom/ ,diakses 15 april 2016)

Suharjanto, Ari 2013 Penerapan Media Pembelajaran dengan Penggunaan Software Prezi dalam Upaya Meningkatkan Minat Belajar Mata Diklat Komunikasi pada Siswa Kelas XI AP 2 SMK Murni 2 Surakarta Tahun Ajaran 2012/ 2013. Skripsi Surakarta Universitas Sebelas maret 